\title{
Otic Dosage Form
}

National Cancer Institute

\section{Source}

National Cancer Institute. Otic Dosage Form. NCI Thesaurus. Code C69040.

A substance intended for administration either on the outer ear or into the auditory canal. 